\title{
A vidékiesség vonzásában: a nagyvárosi agglomerációk láthatatlan turizmusa Magyarországon
}

\section{Attracted by the countryside - invisible tourism in Hungarian urban agglomerations}

\author{
MICHALKÓ GÁBOR, BALIZS DÁNIEL, KISS ÉVA, \\ FARAGÓNÉ HUSZÁR SZILVIA, SIK ANDRÁS, \\ KARÁCSONYI DÁVID
}

MICHALKÓ Gábor: tudományos tanácsadó, MTA CSFK Földrajztudományi Intézet; 1112 Budapest, Budaörsi út 45.; egyetemi tanár, Budapesti Corvinus Egyetem, 1093 Budapest, Fővám tér 8.; michalko.gabor@csfk.mta.hu

BALIZS Dániel: tudományos munkatárs, Budapesti Műszaki és Gazdaságtudományi Egyetem, Urbanisztika Tanszék; 1111 Budapest, Műegyetem rakpart 3.; balizs.daniel@urb.bme.hu KISS Éva: tudományos tanácsadó, MTA CSFK Földrajztudományi Intézet, 1112 Budapest, Budaörsi út 45.; egyetemi tanár, Soproni Egyetem, 9400 Sopron, Erzsébet u. 9.; kisse@helka.iif.hu

FARAGÓNÉ HUSZÁR Szilvia: vezető térségi tervező, Lechner Nonprofit Kft.; 1111 Budapest, Budafoki út 59.; szilvia.huszar@lechnerkozpont.hu

SIK András: térbeli szolgáltatások igazgatója, Lechner Tudásközpont; 1111 Budapest, Budafoki út 59.; andras.sik@lechnerkozpont.hu

KARÁCSONYI Dávid: tudományos munkatárs, MTA CSFK Földrajztudományi Intézet; 1112 Budapest, Budaörsi út 45.; karacsonyidavid@gmail.com

KULCSSZAVAK: turizmus; üdülő; szuburbanizáció; vidék; szabadidő

ABSZTRAKT: A nagyvárosi agglomerációk turisztikai szerepkörének értékelésére vállalkozó tanulmány a vizsgálatba vont térségek üdülőfunkcióját és szálláshelyigényes vendégforgalmát elemezve tárja fel az úgynevezett láthatatlan turizmusban érintett települések körét. Egyrészt a 2001. évi népszámlálás és a TeIR (2002-2014) adataiból kiindulva lehatárolja a különböző mértékű üdülőfunkcióval rendelkező településállományt, majd megvizsgálja az egyes agglomerációk turisztikai keresletében és kínálatában jelentkező disszonanciákat. Az üdülőállományra és a turisztikai piacra vonatkozó adatbázisok összevetése alapján megállapítható, hogy a pécsi és a miskolci agglomerációban szoros összefüggés van az üdülésben és a turizmusban érintett települések vonatkozásában, előbbiben Orfü, utóbbiban Bükkszentkereszt képviseli a konvencionális (regisztrált szálláshelyeket igénybe vevő) és a láthatatlan (a szálláshelystatisztikai adatgyűjtés körén kívül eső) turizmus szimbiózisának színterét. Amíg sem a győri, sem a budapesti agglomerációban nem találkozhatunk ilyen markánsan szembeötlő átfedéssel, addig a fővárost övező térségben Szentendrét a láthatatlan turizmus archetípusaként sikerült azonosítani. Szentendre esetében a regisztrált szálláshelyek

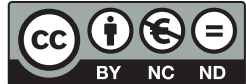


férőhelyeinek túlkínálata alacsony vendégéjszakaszámmal párosul, az üdülőfunkció mértéke, valamint az üdülőingatlanok számának jelentős volumene pedig együttesen felveti a szálláshely-statisztikai adatgyüjtés körén kívüli forgalom jelenlétét. Amíg a jelentős, 24 óránál rövidebb idejü kirándulóforgalmat generáló vonzerők elvétve befolyásolják az üdülőövezetek létrejöttét, addig a nagyvárosi agglomerációk természetközeli, különösen vízparti élményeket kínáló térszínei válnak a vidékies miliőre építő második otthonok melegágyaivá.

Gábor MICHALKÓ: scientific advisor, MTA RCAES Geographical Institute, Budaörsi út 45., H-1112 Budapest, Hungary; professor of tourism, Corvinus University of Budapest, Fővám tér 8., H-1093 Budapest, Hungary; michalko.gabor@csfk.mta.hu

Dániel BALIZS: research fellow, Department for Urban Planning and Design, Budapest University of Technology and Economics; Müegyetem rakpart 3., H-1111 Budapest, Hungary; balizs.daniel@urb.bme.hu

Éva KISS: scientific advisor, MTA RCAES Geographical Institute, Budaörsi út 45., H-1112 Budapest, Hungary; professor, University of Sopron, Erzsébet u. 9., H-9400 Sopron, Hungary; kisse@helka.iif.hu

Szilvia FARAGÓNÉ HUSZÁR: spatial planner, Lechner Nonprofit Ltd.; Budafoki út 59., H-1111 Budapest, Hungary; szilvia.huszar@lechnerkozpont.hu

András SIK: director of geospatial services, Lechner Knowledge Center; Budafoki út 59., H-1111 Budapest, Hungary; andras.sik@lechnerkozpont.hu

Dávid KARÁCSONYI: research fellow, MTA RCAES Geographical Institute; Budaörsi út 45., H-1112 Budapest, Hungary; karacsonyidavid@gmail.com

KEYWORDS: tourism; second home; suburbanization; country; leisure time

ABSTRACT: The study aims to explore settlements involved in the so-called invisible tourism (i.e. not recorded by statistics) within urban agglomerations, by analyzing holiday function vs accommodation (hotel) turnover. We selected settlements with recreation function using the 2001 census and the 2002-2014 TeIR (Spatial Information System of Hungary) data, and analyzed discrepancies between tourism supply and demand in urban agglomerations involving 2015 data of Hungarian Central Statistical Office (KSH). There is a lack of studies about mobility generated by leisure, recreation and tourist activities inside urban agglomerations especially in terms of the relationship between the urban core and the settlements on the fringe providing "rural experiences". While statistics record mostly tourism in the urban core, invisible tourism is typical to the satellite where the secondary home owners and the daily hikers/excursionists do not register accommodation. This research aims to identify the relationship between conventional (i.e. registered) and invisible tourism and the differences between selected Hungarian regional centers in this respect. While the Budapest agglomeration - the largest urban agglomeration in Hungary - provides the most advanced tourism infra- and suprastructure based on the difference between the urban and rural milieus, we can also trace similar processes in other regional urban centers. The comparison of second homes stock (weekend houses) and tourism flow data sets showed strong correlation for Pécs and Miskolc agglomerations. In the former case, Orfü, while in the latter, Bükkszentkereszt represents the symbiosis of conventional (registered) and invisible tourism. In the cases of Györ and Budapest agglomerations, we did not find such overlappings. On the other hand, Szentendre (within the Budapest agglomeration) represents the archetype of invisible tourism: it has a high unrecorded tourist turnover coupled with an oversupply of registered accommodations and few registered hotel nights combined with a high number of second homes. Tourist attractions, generating one-day trips, do not generate a weekend house belt but nature, waterfronts and a rural milieu can be a base for second homes within an urban agglomeration. 


\section{Bevezetés}

A mai nagyvárosok környéke, jóval a szabadidőipar kialakulását megelőzően, nagy népszerűségnek örvendett az európai uralkodóházak jeles képviselői és a hozzájuk közel álló arisztokrácia körében. Ma már a turizmus által hasznosított paloták, kastélyok, foúri rezidenciák sora igazolja a társadalmi elit természetközeli kikapcsolódás, elvonulás iránti vágyának korai megtestesülését (Spirou 2011). Az UNESCO-világörökségek (UNESCO 2016) között számos olyan, a nagyvárosokat övező kulturális turisztikai attrakcióval találkozhatunk, amelyek létrejöttében a vidékiesség egyik attribútuma, a természet közelsége, valamint jó elérhetősége egyaránt szerepet játszott: Versailles-Párizs (világörökségi helyszínné nyilvánítva 1979-ben), El Escorial-Madrid (1984), Drottningholm-Stockholm (1991), Sintra-Lisszabon (1995), Tivoli-Róma (1999) egytől egyig a legmagasabb szintű nemzetközi örökségvédelmet élvező, az adott fővárosból könnyen megközelíthető, a természeti tájba illeszkedő, pompás rezidenciák térszínei.

A 19. század derekától az ipari forradalom és a hozzá kapcsolódó urbanizáció a társadalom egyre szélesedő rétegeiben generálta a nagyvárosok átmeneti jellegű, szabadidős motivációjú elhagyását, e folyamatban a vasúti közlekedés kiépülése meghatározó szerepet játszott (Cocks 2001). A helyi érdekű és az elövárosi vasutak nemcsak a munkahely és a lakóhely között teremtettek összeköttetést, hanem a nagyvárosokhoz közeli szabadidős, rekreációs zónák gyors elérhetőségét is lehetővé tették (Horváth 2006). A motorizáció 20. század második felében végbement rohamos fejlődése serkentően hatott a nagyvárosokat övező üdülőterületek, turisztikai desztinációk fejlődésére (Beluszky 1999a; Jászberényi, Pálfalvi 2009; Tiner 2015). A kötött pályás közlekedés mellett a személygépkocsival és a menetrend szerinti autóbuszjáratokkal történő megközelíthetőség a városban élők üdülőingatlanjainak (nyaraló, hétvégi ház, kiskert, hobbitelek stb.) térhódítását, továbbá a városban tartózkodó vendégek élménybővítését szolgáló turisztikai infra- és szuprasturktúra fejlesztését vonta maga után az agglomerálódó várostérségekben (Selby 2004; Zuelow 2016). A folyamat - a modernizáció fokától, a politikai berendezkedéstől, a társadalmi hagyományoktól és még számos tényezőtől függően - Európa egyes térségeiben, de még egyazon országon belül is különböző ütemben zajlott; mára szinte minden régióban észlelhető a nagyvárosok (jellemzően fővárosok, régióközpontok) és környékük szabadidős, rekreációs, valamint turisztikai szimbiózisa.

A magyarországi városfejlődés a budapesti agglomerációban teremtette meg markánsan a nagyvárosi és a vidéki (természetközeli) miliő különbözőségén alapuló szabadidő-eltöltési igények kielégítését célzó infra- és szuprastruktúrát, de a folyamat a főváros mellett - a jelen tanulmány tárgyát képező - Győr, Miskolc és Pécs esetében is kimutatható. ${ }^{1} \mathrm{~A}$ magyar főváros és az említett regionális központok 19. század második felében megindult, alapvetően ipari termelésen nyugvó modernizációja és növekedése a rendszerváltozás időszakára jól kirajzolódó agglomerációs övezeteket hozott létre, amelyekben a lakófunkció 
mellett a szabadidős, rekreációs és turisztikai szerepkörök egyaránt megtalálhatók (Beluszky 199b; Beluszky, Kovács 1998; Frisnyák 1990). Az egyes agglomerációkhoz tartozó települések kiskertjeiben (zártkertjeiben), vízparti üdülőiben, fürdőiben, erdei túraútvonalain, borpincéiben, műemlékeiben, múzeumaiban, fesztiváljain stb. találkozhatunk az éjszakai tartózkodásra is alkalmas ingatlan jellemzően a közeli nagyvárosban élő - tulajdonosával, családtagjaival, az ingatlant szívességből használó távolabbi rokonokkal, ismerősökkel, valamint az egy napra érkező kirándulókkal. Ugyanakkor a nagyvárosi agglomerációk turisztikai desztinációiban ritkábban fordulnak meg konvencionális, regisztrált szálláshelyet igénybe vevő turisták. Miközben a nagyvárosi agglomerációk turizmusa (a statisztikailag regisztrált vendégéjszakák alapján) döntően a centrumtelepülésen realizálódik, addig az alvóvárosokban és szatellittelepüléseken az üdülőtulajdonosok és a kirándulók szálláshely igénybevétele nélküli láthatatlan turizmusa valósul meg (KSH 2016). A láthatatlan turizmus legfontosabb ismérve, hogy a szálláshely-statisztika nem regisztrálja a forgalmat, továbbá a helyi és térségi turisztikai termékfejlesztés, menedzsment és marketingkommunikáció is rendre figyelmen kívül hagyja jelenlétét, az abból fakadó feladatokat és lehetőségeket (Rátz, Kundi, Michalkó 2015).

Sem a nemzetközi, sem a hazai szakirodalom nem fektetett kellő figyelmet ez idáig a nagyvárosi agglomerációkon belüli szabadidős, rekreációs és turisztikai mobilitás sajátosságainak, a centrum és agglomerációjában fekvő települések közötti kapcsolatoknak a bemutatására. Hiánypótló tanulmányunk már csak a terjedelmi korlátok miatt sem vállalkozhat a probléma komplex feltárására. Célunk a jelenség exponálása, turizmusföldrajzi kontextusának körvonalazása, valamint az agglomerációnak tekinthető (KSH 2014) településegyütteseket érintő, az üdülők és a turisztikai kereslet közötti anomáliákra fókuszáló vizsgálatunk eredményeinek közlése. A kutatás egyrészt arra a kérdésre keresi a választ, hogy milyen különbségek rajzolódnak ki a budapesti, a győri, a miskolci és a pécsi agglomerációk vidékies miliőre építő üdülőövezetei között, másrészt hogy kimutatható-e bármilyen összefüggés ezen települések konvencionális (regisztrált szálláshelyeket igénybe vevő) és láthatatlan (a szálláshely-statisztikai adatgyűjtés körén kívül eső) turizmusa között.

\section{Elméleti háttér}

Az elméleti csomópontban a nagyvárosi agglomerációkban elhelyezkedő második otthonok állnak, amelyek egyrészt a helyi lakosság különböző időtartamú környezetváltozását, rekreációs tevékenységét szolgáló üdülőingatlanként, másrészt az adott településen turistaszerepben megjelenő rokonoknak, barátoknak átengedett szívességi szálláshelyként értelmezhetők (Vepsäläinen, Pitkänen 2010). Miközben a második otthonok lényeges szerepet töltenek be a 
szuburbanizáció folyamatában (Dahms, McComb 1999; Dövényi, Kovács 1999), az érintett, jobbára falusias arculatú települések, a tradicionális hétvégi házas, hobbikertes övezetek modernizációja, fokozatos funkcióváltása a térség turizmusában a korábban vonzerőt jelentő rurális miliő erodálását eredményezheti (Liu, Li, Tang, Wang, Li 2015). Torreggiani, Dall'Ara, Tassinari (2012) arra hívják fel a figyelmet, hogy a szuburbanizáció következtében a vidék ugyan veszít a falusias jellemvonásaiból, azonban egy fordított folyamatnak köszönhetően a városokban megjelennek, illetve markánsabbá válnak a mezőgazdasághoz kapcsolható terek (kiskertek, borospincék, halastavak, lovardák stb.), amelynek következtében módosul a településdizájn.

A nagyvárosi agglomerációk funkcióbővülésének jól kirajzolódó eleme a közlekedési, kiskereskedelmi, kulturális és sportszolgáltatások térhódítása. A légi közlekedés iránti kereslet gyors növekedése miatt a repülőtéri kapacitásokat bővíteni kellett (föleg a diszkont légitársaságok piacra lépésével és terjeszkedésével), valamint új közlekedési kapcsolatokat és infrastruktúrát (pl. reptéri vasútvonalakat, gyorsforgalmi utakat, új buszjáratokat, reptér környéki szállodákat és kiskereskedelmi zónákat) kellett létrehozni (Nucciarelli, Gastaldi 2009). A lakossági fogyasztás kiemelt szerepet élvez a városkörnyéki szolgáltatások sorában (Teller, Elms 2012), a hiper- és szupermarketek, szakáruházak felkeresése sajátos szabadidős, élményszerző tevékenységet is jelent a vásárlók számára (Timothy 2004; Tömöri 2012). A nagyvárosi agglomerációk egyes településein, ahol a falusi ipar tradicionális elemeit sikerült megőrizni, a kézműves műhelyek termékeit szuvenírként értékesítik (Zeng, Zhu 2011). A kulturális, kiváltképpen a zenei és összművészeti fesztiválokhoz, a szabadtéri színházi előadásokhoz és gasztronómiai rendezvényekhez kötődő kínálat színesíti a nagyvárosi agglomerációk szolgáltatásait (Mills, Rosentraub 2013; Sava, Caraivan 2012). A relatíve szerény bevételeket hozó aktív szabadidő-eltöltés (pl. kirándulás az erdőben, kerékpártúrázás, fürdőzés a szabad strandon) nyújtása mellett az agglomerációk a nagy térigényü, ugyanakkor jól megközelíthető sportturisztikai nagyberuházások kedvelt színterei is, így stadionokat, golfpályákat, autó- és motorversenyekre szolgáló létesítményeket egyaránt szívesen telepítenek a nagyvárosok határában fekvő településekre (Baade, Dye 1990; Kiss 2014; Pintilii, Merciu, Peptenatu, Cercleux, Drăghici 2011).

Az agglomerációs térség táji sajátosságai mellett a településállomány sürűsége is befolyással van a turizmusra. Egy kínai kutatás többek között azt állapította meg, hogy a sűrübb textúrájú nagyvárosi övezetekben fekvő települések turizmusa fejlettebb (Yang 2012). Evert (2008) hollandiai nagyvárosi régiókban végzett vizsgálata kimutatta, hogy a policentrikus agglomerációkban szűkebb a kulturális, szabadidős és sportszolgáltatások hozzáférhetősége a monocentrikusokhoz képest. Hwang, Gretzel, Fesemaier (2006) felhívták a figyelmet arra, hogy az agglomerációk kínálati elemein, illetve a szuburbán zónák térszerkezetén túlmenően a települési és térségi menedzsment is befolyásolja az agglomerációk munkamegosztását, a szabadidős, rekreációs és turisztikai kereslet 
mértékét. Az USA városrégióiban végzett kutatás szerint az egyazon utazás alatt meglátogatott városok száma - sok más tényező együttes hatása mellett - nagymértékben függ a marketingkommunikációtól és a közösségi médiákban elérhető információktól. A marketingkommunikáció sikerét az agglomerációt érintő komplex, a turizmust is integráló, arról rendszerként gondolkodó tervezés is befolyásolja (Stan, Tenea, Vintila 2014).

Miközben a vízparti térségben elhelyezkedő üdülőingatlanok (második otthonok) igénybevétele miatti forgalmat a szerzők a vizsgált települések turizmusaként értelmezik (Tuohino, Dávid 2012), addig a nagyvárosi agglomerációk hétvégi házainak használata sokkal inkább a szabadidő-eltöltés, rekreáció fogalmi mezőjében marad (Bánhidi 2016). Az érzékelhető különbségtétel mögött vélhetően az adott település turisztikai szerepköre húzódik meg. Amennyiben a helység rendelkezik olyan vonzerővel, amely képes vendégéjszakákban mérhető forgalmat generálni, akkor a szerzők az üdülőingatlanokat hasznosítók keresletére is hajlamosak turizmusként tekinteni, amennyiben nincs számottevő vonzerő, ebből kifolyólag nem jelenik meg a konvencionális turisztikai kereslet, akkor csak az üdülőhasznosítók jelenlétét konstatálják (Hall, Müller 2004).

Az üdülőingatlant hasznosítók lényegében láthatatlan turistaként értelmezhetők, mivel a településen átmenetileg, szabadidejük eltöltése céljából tartózkodnak, tevékenységük környezetváltozással és élményszerzéssel párosul, igénybe veszik a helyi szolgáltatásokat (elsősorban a kiskereskedelemben, vendéglátásban), sőt, a szabadidőipar kínálatának más szolgáltatásait is (Michalkó, Kádár, Balizs, Kondor, Ilyés 2016). A láthatatlan turizmus megítélése szempontjából nincs lényegi különbség a szálláshelyigényes turisták által frekventált és a vendégforgalomtól távolabb fekvő települések között. Ha az adott helységben realizálódik a regisztrált szálláshelyeken kívüli éjszakai tartózkodás vagy bármilyen turisztikai vonzerő gerjesztette egynapos (kiránduló)forgalom, akkor ott a láthatatlan turizmus jelenlététről van szó (Michalkó, Rátz 2013). Tehát a láthatatlan turizmus jellemzője, hogy az adott településen tartózkodók kereslete a rendszeres szálláshely-statisztikai adatgyüjtés körén kívül esik, illetve a turizmussal összefüggő tevékenység egyáltalán nem, vagy nehezen mérhető (De Cantis, Parroco, Ferrante, Vaccina 2015).

\section{Módszer}

A láthatatlan turizmus feltárására hivatott vizsgálatok egyik legnagyobb kihívása az elemzésre alkalmas adatbázisok összeállítása, mivel a láthatatlanság kulcsattribútuma a célirányos és rendszeres statisztikai adatgyüjtés hiánya (Asero 2009; Ostertag, Wöber 2010; Wood, Guerry, Silver, Lacayo 2013). Ebből következően az empirikus vizsgálatok szolgálják a láthatatlan turizmus megismerését, nyújtják azt az eszköztárat, amelyek között már a legkorszerűbb tech- 
nológiát alkalmazó, GPS-alapú elemzésekkel is találkozhatunk (Kádár, Gede 2013; Lo, McKercher, Lo, Cheung, Law 2011; Straumann, Çöltekin, Andrienko 2014). Ugyanakkor - ahogy esetünkben is - bizonyos statisztikai számbavételek összevetése alkalmas lehet a konvencionális turisztikai mobilitás határán lévő, vagy azon kívül eső szabadidős, rekreációs motivációjú utazások bemutatására (Rátz, Puczkó 2002). Például a turisztikai infrastruktúra hasznosítását igazoló jegyeladások (fürdő- vagy múzeumi belépők) azokon a településeken is képesek tükrözni a láthatatlan turizmus tényét, ahol a regisztrált szálláshelyek vendégéjszakáinak száma elenyésző (Szentendre). ${ }^{2}$

A jelen tanulmány a KSH 2001. évi népszámlálásában összeírt üdülők számát és az üdülőknek az adott település összes lakóegységén belüli arányát veszi alapul. Egy településen az üdülők aránya utalhat arra, hogy mekkora az adott helység szabadidős, rekreációs, turisztikai szerepköre, mivel az üdülők „a lakásforgalomban meghatározott kritériumoknak lényegében megfelelö, azonban az egész éven át tartó, állandó használatra általában nem alkalmas ingatlanok" (http://www.nepszamlalas2001.hu), így pusztán létezésük segíti a turizmus egyik lényegi tényezőjének, az átmeneti tartózkodásnak kimutatását. Tudvalevő, hogy az üdülőingatlanok ${ }^{3}$ építésének fénykora a rendszerváltozást megelőző évtizedekre esett, de ha lassuló ütemben és csökkenő volumenben is, 1990 után sem szűnt meg az igény az ilyen jellegü épületek létrehozására (Aubert, Papp 2015; Csordás 1993, 2010). Mivel a 2011-es népszámlálás alkalmával már nem került sor az üdülőingatlanok teljes körű összeírására, így a 2002-2014-es időszakra a Lechner Nonprofit Kft. által üzemeltetett Országos Területfejlesztési és Területrendezési Információs Rendszer (TeIR) adatállományát hasznosítottuk.

Miközben az üdülőingatlanok csupán közvetetten jelzik az adott település szabadidős, rekreációs és turisztikai hasznosítását, addig a regisztrált szálláshelyek piaca, különösen a tényleges keresletet mutató vendégéjszakák száma egyértelműen igazolja a konvencionális turizmus jelenlétét. A KSH Tájékoztatási Adatbázisából a legutóbbi lezárt évet (2015) alapul véve kigyüjtöttük a kereskedelmi és a magánszállásadás kínálati (férőhelyek), valamint keresleti (belföldi és külföldi vendégek és vendégéjszakák) adatait.

A vizsgálatba vont magyarországi agglomerációkban - a 2001. évi népszámlálási adatokat véve figyelembe - az üdülők összes lakóegységen belüli aránya alapján csoportosítottuk az üdülőingatlannal rendelkező, illetve nem rendelkező településeket, majd a 6 kategóriába sorolt helységeket kartodiagramon ábrázoltuk (1-2. ábra). (Előfordult, hogy a települések összevonása vagy szétválása miatt az adott helységről nem álltak rendelkezésünkre adatok, ezt a kartodiagramon „nincs adat”-ként jelöltük.) Ezt követően megvizsgáltuk, hogy egyrészt melyek azok a települések, amelyekben 2001 után is folytatódott az üdülőingatlanok létrehozása, másrészt hogy melyek azok a városok és községek, amelyek területén csupán 2001-et követően kezdődött meg az üdülőépítés. Mindkét esetben a 2002-2014 közötti időszakra eső növekményt (az újonnan létrejött üdülőingatlanok számát) kartodiagramon ábrázoltuk (1-2. ábra). Mivel 
a tanulmány elsődleges célja a láthatatlan és a konvencionális turizmus közötti összefüggések feltárása volt, ezért a budapesti, a győri, a miskolci és a pécsi agglomerációban egyaránt vizsgálat tárgyává tettük az üdülővel való ellátottság, valamint a regisztrált szálláshelyek keresletének, kínálatának kereszttáblákban kimutatható összefüggéseit.

\section{Eredmények}

\section{A nagyvárosi agglomerációk üdülőfunkciója}

A 2001-es népszámlálás adatai szerint a 81 települést magába foglaló budapesti agglomerációban a helységek 48\%-ában „nincs vagy elhanyagolható mértékü” (0-9,9\%) a lakóegységeken belül az üdülőingatlanok részesedése. Számottevő az „alacsony” (10,0-19,9\%) és a „közepes” (20,0-29,9\%) részesedésü települések csoportja, a települések 16\%, illetve 19\%-ával. A „magas” (30,0-39,9\%) és a ,jelentős” (40,0-49,9\%) részesedésű helységek együttes súlya $12 \%$, míg „domináns" (50\% feletti) üdülóállomány mindössze a települések 5\%-ában mutatható ki. A budapesti agglomeráción belül jól kirajzolódik egy üdülöövezeti gócpont, amelyet az egymással határos, a Szentendrei-sziget tájképi szépségére és a Duna közelségére építő Pócsmegyer (75,4\%), Szigetmonostor (69,6\%) és Leányfalu (62,8\%) képez (1.ábra).

A budapestivel ellentétben a győri, a miskolci és a pécsi agglomerációban szinte ki sem mutatható a „domináns" üdülő funkció, egyedül a pécsi agglomerációban regisztrálták az üdülőingatlanok lakóegységeken belüli, 50\%-ot meghaladó részesedését (2. ábra). A Vízfö-forrás karsztvize táplálta mesterséges Orfüi-tórendszer mentén fekvő Orfün 78,7\% az üdülőingatlanok aránya. Mivel a szomszédos Abaliget - Orfühöz hasonlóan - igen jó természeti adottságokkal (pl. csónakázótó, barlang) rendelkezik, az üdülőfunkció a „domináns” kategória közelében van (49,4\%). A Duna és a Mosoni-Duna közé ékelődő Vének a győri agglomeráció egyetlen ,jelentős” (47,5\%) üdülőfunkcióval rendelkező települése; a miskolci agglomerációban három, e kategóriába eső helységgel is találkozhatunk. A vízparti rekreáció szinte teljes vertikumát kínáló kavicsbányatavak mentén elhelyezkedő Nyékládháza $(43,5 \%)$ és Mályi $(43,1 \%)$ mellett a Bükk kapuját és a hazai síturizmus egyik fellegvárát jelentő Bükkszentkereszt $(43,6 \%)$ a miskolci agglomeráció ,jelentős” üdülőfunkciójú települései. Győr, Miskolc és Pécs agglomerációjához tartozó településállomány négyötödében „nincs vagy elhanyagolható mértékü” az üdülők lakóegységeken belüli részesedése.

A 2001. évi népszámlálás adatai szerint a budapesti agglomerációban közel 42 ezer üdülőingatlant regisztráltak, a teljes ingatlanállomány e szegmense 


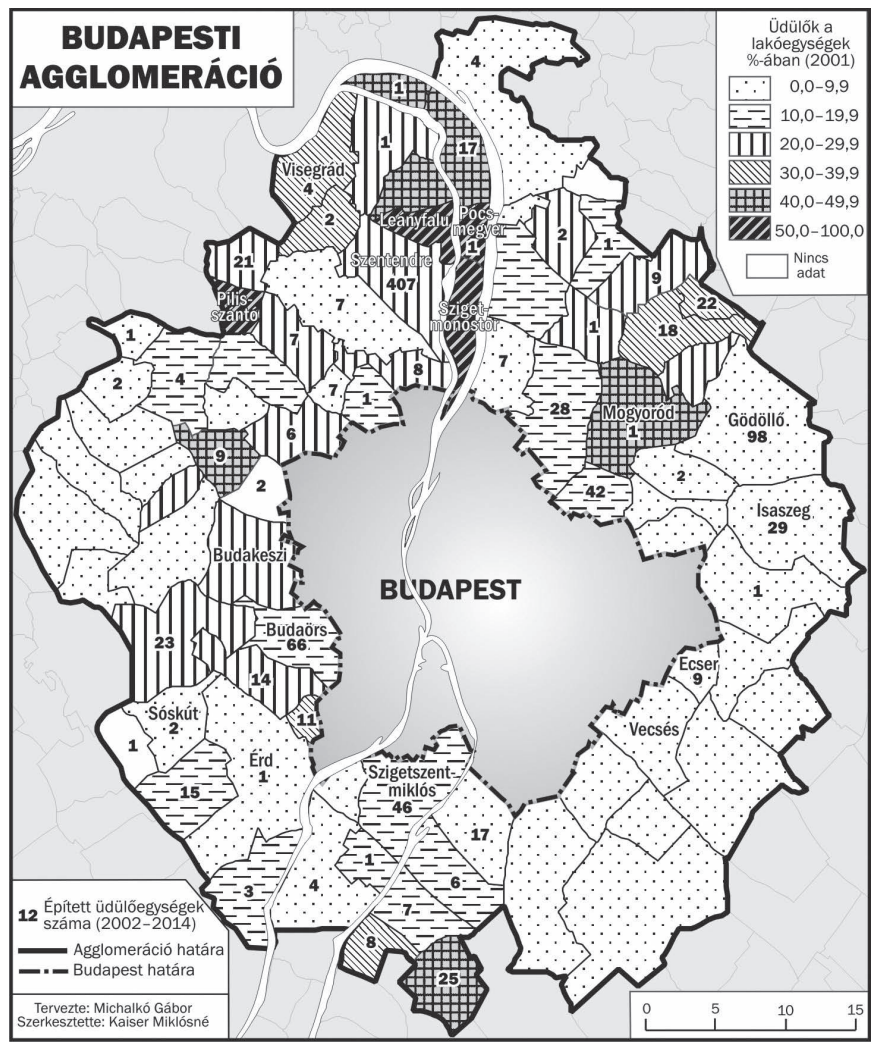

mindössze 1613 egységgel (+3,8\%) növekedett 2002 és 2014 között (1. ábra). Volumen tekintetében Szentendre üdülőinek száma emelkedett a legnagyobb mértékben (+407 egység), de Gödöllő (+98 egység), Budaörs (+66 egység) és Szigetszentmiklós (+46 egység) növekedése is számottevő volt. A 2002 utáni évtizedben érdemi átrendeződés nem következett be az üdülőállományban. Szentendre inkább kivételnek tekinthető, mivel a markáns 2001. évi bázis számottevően bővült, a többi, jelentékeny (1000 egység feletti) üdülőingatlannal rendelkező településen ilyen mértékủ növekmény nem volt kimutatható. A „domináns" üdülőfunkcióval rendelkező településeken az 1\%-ot sem haladta meg az állomány bővülése. Az üdülőfunkcióval 2001-ben alapvetően „nem vagy minimális mértékben" rendelkező településállományt vizsgálva Isaszeg $(+725 \%)$, Sóskút $(+50,0 \%)$, Gödöllő $(+38,7 \%)$ és Ecser $(+11,3 \%)$ eseteiben lehetett említésre méltó (10\%-ot meghaladó) üdülőingatlan-bővülést regisztrálni, de az alacsony bázis miatt 2002 és 2014 között egyik település sem vált a budapesti agglomeráció üdülőövezetének szerves részévé. 


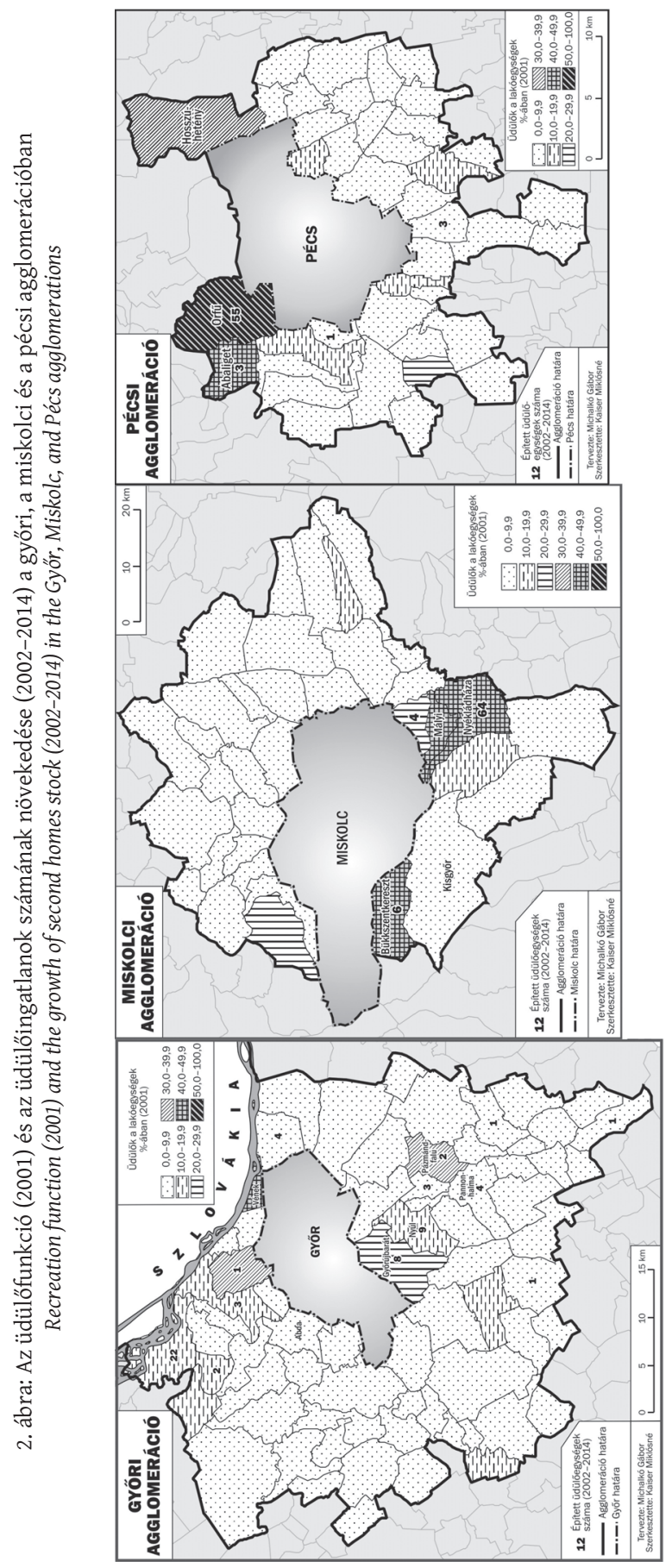


1. táblázat: A vendégéjszakák száma a nagyvárosi agglomerációk kereskedelmi és magánszálláshelyein (2015)

Number of guest nights in hotels and apartments of urban agglomerations (2015)

\begin{tabular}{lccc}
\hline \multicolumn{1}{c}{ Agglomeráció } & Centrum & Agglomerációs övezet & Összesen \\
\hline Budapesti & 10008751 & 598160 & 10606911 \\
Győri & 351110 & 16690 & 367800 \\
Miskolci & 364815 & 12403 & 377218 \\
Pécsi & 255081 & 95386 & 350467 \\
\hline
\end{tabular}

Forrás: KSH Tájékoztatási adatbázis.

A budapestihez viszonyítva a győri, a miskolci és a pécsi agglomerációban 2002 és 2014 között bekövetkező változások elvétve befolyásolták az üdülők számának növekedését (2. ábra). A győri agglomerációban a Mosoni-Duna menti Ásványrárón a 2001. bázisév 112 üdülőjéhez képest 22-vel nőtt az egységek száma, de a „domináns” üdülőfunkcióval rendelkező Véneken egyetlen üdülöegységgel sem bővült az állomány. A miskolci agglomerációban szinte kivétel nélkül a ,jelentős" üdülőfunkciójú települések további bővülése mutatható ki, közülük Nyékládházán (+64 egység) regisztrálták a legnagyobb volumenű növekedést. A pécsi agglomerációban Orfü (+55 egység) tovább erősítette üdülőfunkcióját, míg Abaligeten a vizsgált időszakban mindössze 3 egységgel emelkedett az üdülők száma, új település itt sem került az üdülőövezeti térképre.

2. táblázat: Néhány kiemelt település szabadidős, rekreációs és turisztikai szerepe a budapesti agglomerációban

Leisure, recreation and tourism functions of selected settlements in the Budapest agglomeration

\begin{tabular}{|c|c|c|c|c|}
\hline Település & $\begin{array}{c}\text { Az üdülők aránya az } \\
\text { összes lakóegység } \\
\text { \%-ában (2001) }\end{array}$ & $\begin{array}{c}\text { Az üdülök részesedése } \\
\text { az agglomeráció } \\
\text { összes üdülőjéból, \% } \\
\text { (2001) }\end{array}$ & $\begin{array}{c}\text { A féröhelyek } \\
\text { részesedése az } \\
\text { agglomeráció összes } \\
\text { férőhelyéból, \% (2015) }\end{array}$ & $\begin{array}{c}\text { A vendégéjszakák } \\
\text { részesedése az } \\
\text { agglomeráció összes } \\
\text { vendégéjszakájából, \% } \\
\text { (2015) }\end{array}$ \\
\hline Pócsmegyer & 75,4 & 3,6 & 0,0 & 0,0 \\
\hline Szigetmonostor & 69,6 & 3,8 & 0,0 & 0,0 \\
\hline Leányfalu & 62,8 & 3,6 & 0,7 & 0,1 \\
\hline Pilisszántó & 52,6 & 2,0 & 0,0 & 0,0 \\
\hline Visegrád & 32,5 & 0,8 & 22,5 & 37,3 \\
\hline Vecsés & 0,1 & 0,0 & 9,3 & 16,2 \\
\hline Budaörs & 15,8 & 4,0 & 9,0 & 14,3 \\
\hline Gödöllő & 2,2 & 0,6 & 14,2 & 8,5 \\
\hline Szentendre & 23,1 & 6,1 & 9,0 & 4,2 \\
\hline Mogyoród & 41,1 & 2,6 & 6,0 & 0,5 \\
\hline Érd & 9,6 & 5,0 & 0,9 & 0,2 \\
\hline Budakeszi & 28,3 & 4,8 & 2,2 & 0,9 \\
\hline
\end{tabular}

Forrás: KSH 2001, KSH Tájékoztatási adatbázis. 


\section{A nagyvárosi agglomerációk konvencionális és láthatatlan turizmusa}

A nagyvárosi agglomerációk konvencionális turizmusának szembeötlő tulajdonsága, hogy a férőhelykínálat és a szálláshelyigényes vendégforgalom igen tekintélyes hányada egyaránt a centrumban realizálódik. Ez a fajta koncentráció Budapest (94,4\%), Győr (95,5\%) és Miskolc (96,7\%) esetében rendkívül erős, de Pécsen $(72,8 \%)$ is számottevő (1. táblázat). Természetesen nem szabad megfeledkeznünk arról, hogy a budapesti agglomerációs övezetben közel ötször annyi a vendégéjszakák száma, mint a másik háromban együttvéve, így az összehasonlítás csak a centrumokban összpontosuló vendégforgalom jelenségére utal.

A kereskedelmi és magánszálláshelyek férőhelyeinek és/vagy az ott eltöltött vendégéjszakáknak 2015. évi súlya a budapesti agglomeráció 81 településéből mindössze 12-ben haladta meg az egy településre jutó átlagos számot (2. táblázat). A legnagyobb arányú férőhelykapacitással (22,5\%) és vendégforgalommal (37,3\%) a Dunakanyar ékköve, Visegrád rendelkezik, elsősorban wellness szállodáinak köszönhetően. A Budapest-centrikus hivatásturizmus keresletével magyarázható Vecsés $(16,2 \%)$ és Budaörs $(14,3 \%)$ vendégéjszakáinak magas részesedése. Az előbbi három település bonyolítja a budapesti agglomerációban realizálódó, szálláshelyigényes vendégforgalom kétharmadát. A Grassalkovichkastéllyal rendelkező Gödöllő, a Szabadtéri Néprajzi Múzeumot (skanzent) és a páratlan hangulatú sétálóutcákat kínáló Szentendre kiváló példája annak, hogy a településeken jelentkező igen tekintélyes kirándulóforgalom nem párosul vendégéjszakákban mérhető kereslettel. Gödöllőn a 14,2\%-os férőhelykapacitás mindössze 8,5\%-os vendégéjszakasúlyt eredményez, míg Szentendre esetében az előbbi mutató értéke 9,0\%, az utóbbié 4,2\%. Mogyoródon még erősebb a kínálat és a kereslet disszonanciája, a Formula-1 Magyar Nagydíjnak 1986 óta otthonul szolgáló település turizmusa oly mértékben szezonális, hogy a 6\%-os férőhelykapacitás mindössze 0,5\% arányú forgalommal párosul.

A 2001. évi népszámláláskor összeírt üdülők súlya a budapesti agglomerációban fekvő 81 településből 28 esetben haladta meg az egy településre jutó átlagot. Az üdülők számában a legnagyobb aránnyal rendelkező települések között találjuk Szentendrét (6,1\%), Érdet (5,0\%) és Budakeszit (4,8\%). Miközben a Szentendre közigazgatási területén található skanzen éves regisztrált forgalma százezres nagyságrendű és belvárosa a főváros nemzetközi autóbuszos utaztatásban legaktívabb utazási irodáinak fél- és egynapos célterülete, addig sem Érd, sem Budakeszi nem tartozik a budapesti agglomeráció turizmusában számottevő vonzerővel rendelkező, érdemi forgalmat generáló települései közé. A jelentős kereskedelmi és magánszálláshellyel, illetve vendégforgalommal rendelkező települések közül Szentendre (6,1\%) mellett Budaörs $(4,0 \%)$ és Mogyoród (2,6\%) üdülősúlya lépi át az agglomerációs átlagot, Visegrád $(0,8 \%)$, Gödöllő $(0,6 \%)$ és Vecsés $(0,0 \%)$ egyaránt alatta maradnak (2. táblázat). A „domináns" üdülőfunkciójú településeket vizsgálva Szigetmonostor (3,8\%), Leányfalu és Pócsmegyer (egyformán 3,6\%), továbbá Pilisszántó $(2,0 \%)$ is a bu- 
dapesti agglomeráció átlagot meghaladó települései közé tartozik, azonban a férőhelykapacitásban és a vendégéjszakában a regisztrált szálláshelyekhez kötődő keresletük nem számottevő.

A budapestivel ellentétben a győri, a miskolci és a pécsi agglomerációban koncentráltabb a kereskedelmi és a magán szálláshelyek piaca. A győriben három település, Abda $(35,8 \%)$, Nyúl $(23,6 \%)$ és Pannonhalma $(12,4 \%)$ bonyolította 2015-ben a szálláshelyigényes forgalom közel háromnegyedét, a miskolciban Bükkszentkereszt (92,2\%), a pécsiben Orfü (76,1\%) dominált. Amíg a miskolci agglomeráció koncentrációjára jellemző, hogy Bükkszentkereszt mellett csupán Kisgyőrben (7,8\%) regisztráltak vendégéjszakát, addig a győriben tíz, a pécsiben nyolc település érintett a szálláshelyek igénybevételében. Győr esetében figyelemre méltó, hogy a számottevő turisztikai vonzerővel nem rendelkezö, ugyanakkor a foútvonalak mentén, a megyeközpont határában fekvő Abda és Nyúl (vélhetően átmenő, illetve munkavállalással összefüggő) forgalma jelentősen meghaladja a világörökségi helyszínként ismert Pannonhalmáét.

A győri agglomerációban elvétve akad olyan település, amely a magánés/vagy a kereskedelmi szállásadásban és a térség üdülőfunkciójában is érdemi szerepet töltene be. Abdán a 2001. évi népszámlálás adatai alapján egyáltalán nem volt üdülő, Pannonhalma a térség üdülőinek mindössze 1,8\%-ával rendelkezett, Nyúl azonban már 11,8\%-ával. Az üdülőingatlanok súlyát tekintve a „jelentős” részesedésű Győrújbaráton (26,9\%) szálláshelyigényes turisztikai kereslet is észlelhető (az agglomeráció forgalmának 8,8\%-a), ugyanakkor a nagyobb üdülólllománnyal rendelkező Pázmándfaluban (10,0\%) nem regisztráltak vendégéjszakát. A térség egyetlen ,jelentős” üdülőfunkciójú települése Vének, az agglomeráció üdüloállományának 3,2\%-ával, de esetében sem regisztráltak szálláshelyigényes forgalmat.

A miskolci agglomerációban a szálláshelyigényes keresletben szinte monopolhelyzetű Bükkszentkereszt a térség üdülőállományának 11,4\%-ával rendelkezik, maga is ,jelentős” üdülőfunkciójú település, azonban a hasonlóan „jelentős” üdülőfunkciójú kategóriába sorolt Mályin és Nyékládházán (együttesen a térség üdülőállományának 68,1\%-ával) nem regisztráltak vendégéjszakát.

A pécsi agglomerációban fekvő Orfü a kereskedelmi és magánszálláshelyeken eltöltött vendégéjszakák, a térség üdülőállományában való részesedés $(50,1 \%)$ és a „domináns” üdülőfunkció alapján a baranyai megyeszékhelyet övező szabadidős, rekreációs, turisztikai övezet legvonzóbb települése. „Versenytársai" között az ugyancsak tekintélyes üdülősúlyú (28,8\%) és magas üdülőfunkciójú $(37,4 \%)$ Hosszúhetény és a szomszédos, 9,5\%-os térségi üdülőrészesedésű, ,jelentős” üdülőfunkciójú Abaliget szálláshelyigényes kereslete messze elmarad Orfü mutatójától.

A szálláshely-statisztikai értelemben láthatatlan turizmus láthatóvá tételére használt proxy mutatók - az üdülőknek az adott település ingatlanállományán belüli aránya (funkció), illetve egy település üdülőingatlanjainak az 
adott agglomeráción belüli súlya (koncentráció) - megfelelő kiindulási alapot képeznek a konvencionális turizmuson kívüli kereslet megfigyelésére. A rendszerváltozás után az üdülőingatlanok használatában bekövetkezett változás azonban korlátozhatja a messzemenő következtetések levonását, illetve további, kérdőívezésre alapozott vizsgálatokat tesz szükségessé.

Az üdülőhasználók - legyenek azok a tulajdonosok vagy szívességből befogadott rokonaik, ismerőseik, esetleg a szürkegazdaságban értékesített részidőre érkezők - egyaránt láthatatlan turistaként viselkednek, mivel igénybe veszik a helyi szabadidős, kiskereskedelmi, vendéglátóipari szolgáltatásokat, terhelik az úthálózatot és a településkörnyezetet, azonban a szálláshely-statisztikában nem jelennek meg. Ugyanakkor az üdülőingatlanok akár állandó lakóhelyként vagy tartózkodási helyként is funkcionálhatnak. Különösen a nagyvárosi agglomerációkban jellemző, hogy az együtt élő háztartásokból a fiatalabb vagy az idősebb generáció az üdülőbe költözik. De nem kizárt az üdülők „munkásszállásként” történő hasznosítása sem, vagyis a közeli centrumtelepülésen dolgozók számára albérletként való értékesítése. Jelen vizsgálat ugyan közvetlenül nem tudta igazolni az üdülők funkcionális sokszínüségét, de több esetben is vélelmezni lehetett, hogy akár a funkciót, akár a koncentrációt tartalmazó mutatószám mögött nem csupán szabadidős, rekreációs és turisztikai tényezők, hanem más ingatlan- és munkaerő-piaci folyamatok is meghúzódhatnak.

\section{Összefoglalás}

A nagyvárosi agglomerációk meghatározó szerepet játszanak Magyarország turizmusában, a konvencionális, regisztrált szálláshelyen töltött vendégéjszakákkal párosuló belföldi és nemzetközi turizmus mellett az úgynevezett láthatatlan, 24 óránál rövidebb tartózkodási idejü, valamint a saját tulajdonú üdülőkben vagy szívességi szálláshelyeken realizálódó forgalom is jelen van. A vizsgált nagyvárosi agglomerációk turizmusa kivétel nélkül a centrumtelepülésen koncentrálódik, Budapest, Győr, Miskolc és Pécs nemcsak közlekedési csomópontok, hanem a turisztikai kínálat, a vonzerő, az infrastruktúra, valamint a szálláshelyek és vendéglátóipari egységek koncentrációi is. A centrumtelepülések - a turizmusstatisztika rögzítette forgalom bonyolítása mellett - részt vesznek a nem regisztrált kereslet igényeinek kielégítésében is, különösen szívességi szálláshely biztosítása révén. Minél nagyobb a centrum lakosságszáma, annál nagyobb a láthatatlan turizmusban való érintettsége, az 1,7 millió helyi lakost számláló Budapest tehát Magyarországon a rokonok és barátok meglátogatásának a fellegvára.

A nagyvárosi agglomerációk centrumtelepüléseit övező, a vidékiesség lényegi attribútumát, a természetközeliség élményét kínáló településállomány - né- 
hány nemzetközi és országos vonzerővel rendelkező helységtől eltekintve - regionális hatókörű szabadidős és rekreációs térségek. Sem a nemzetközi érdeklődésre számot tartó mogyoródi Formula-1 autóverseny, sem a világörökség részét képező Pannonhalmi Bencés Főapátság nem képes számottevő vendégforgalmat generálni az adott desztinációk szálláshelyein, de országos vonzerejű agglomerációs települések - mint Gödöllő vagy Szentendre - sem kerülnek a turizmusstatisztika élmezőnyébe. A nagyvárosi agglomerációk települései közül kizárólag Visegrádon haladja meg a 100 ezret a vendégéjszakák száma, ahol a kulturális turisztikai kínálatot wellness szállodákkal bővítették. A pécsi agglomerációhoz tartozó Orfü (a fesztiválturizmusban való látványos erősödése ellenére) és a miskolci agglomerációban fekvő Nyékládháza alapvetően regionális vonzerőt képviselnek. A centrumot leszámítva a nagyvárosi agglomerációk településeinek döntő többsége nem vesz részt Magyarország konvencionális turizmusában, de még az érdemi látogatóforgalmat bonyolító helységek sem tudják vendégeiket éjszakára is marasztalni, a vendégek inkább hazavagy továbbutaznak, vagy visszatérnek a kiindulási helyül szolgáló centrumba.

Annak ellenére, hogy a nagyvárosi agglomerációk centrumait övező településállomány nem esik Magyarország vendégforgalmának fó áramaiba, a vizsgált térségek üdülőként hasznosított ingatlanállománya lehetőséget biztosít a láthatatlan turizmusba történő bekapcsolódásra. Miközben a győri, a miskolci és a pécsi agglomeráció településállományában az üdülőfunkcióban elvétve vannak jelentős vagy domináns szerepkörü helységek, addig a budapesti agglomerációban már jóval nagyobb arányú a kifejezetten szabadidős és rekreációs igényeket kielégítő település. Általánosságban is megállapítható, hogy a többi nagyvárosi agglomerációval összehasonlítva a budapesti agglomerációban jóval magasabb az érdemleges üdülőfunkcióval rendelkező települések aránya. Feltételezve, hogy az agglomerációk üdülőtulajdonosainak többsége a centrumtelepülés lakosa, a sűrübb beépítettségü, zsúfoltabb Budapest lakosságának környezetváltozást kínáló, vidékies miliő iránti igénye magyarázhatja a centrum környéki üdülőingatlanok magasabb arányát. Az üdülők szabadidős, rekreációs tevékenysége, a konvencionális turistákéhoz hasonló fogyasztói magatartása, továbbá az ingatlanok szívességi szálláshelyként történő átengedése regisztráció nélküli, láthatatlan turizmust generál az érintett településeken.

Magyarországon a nagyvárosi agglomerációk közül Szentendre a vidékiesség vonzására építő láthatatlan turizmus archetípusa, mivel - a Szabadtéri Néprajzi Múzeum révén - területén jelentős kulturális turisztikai kereslet realizálódik, amely kiegészül az egyedülálló atmoszférájú településközpont kínálatával. Ugyanakkor az évi százezres látogatóforgalom alig párezer vendégéjszakát eredményez a település regisztrált szálláshelyein. Szentendrén fekvésének, a Duna közelségének köszönhetően a budapesti agglomeráció legnagyobb üdülő́llománya jött létre, amely dinamikusan bővült a rendszerváltozás előtt és után is.

Egy átfogó - tehát az üdülő tulajdonosaira és használóira, valamint a helyi szolgáltatókra egyaránt kiterjedő - kérdőíves vizsgálat feladata lesz, hogy ponto- 
sabb képet alkothassunk az üdülőingatlanok láthatatlan turizmusban betöltött szerepéről. Vélelmezhető, hogy a magyarországi nagyvárosi agglomerációkban az elmúlt évtizedekben lezajlott szuburbanizációs folyamatok a tradicionális üdülőzónáktól (pl. Balaton) eltérő üdülőhasznosítási magatartásformákat hoztak létre. Ezzel összefüggésben a vizsgált térségek láthatatlan turizmusában is markáns különbségek észlelhetők. Azokban a településekben és térségekben, amelyek érintettek a nagyvárosi agglomerációk láthatatlan turizmusában, a menedzsmentnek a jövőben nagyobb figyelmet kell fordítania az üdülőhasznosítás révén jelentkező kereslettel kapcsolatos szabályozási, termékfejlesztési és marketingkommunikációs feladatokra, az azokban rejlő lehetőségek kiaknázására, a centrum- és a szomszédos településekkel való turisztikai együttműködés hatékonyságának fokozására.

\section{Jegyzetek}

1 A Központi Statisztikai Hivatal (KSH 2014) a Budapest, Győr, Miskolc és Pécs környékén létrejött településegyütteseket tartja nyilván nagyvárosi agglomerációként.

2 Napjainkban a legtöbb, szabadidős szolgáltatásokat kínáló településen a helyi lakosság számára igénybe vehető az úgynevezett településkártya, amely jelentős kedvezményeket biztosít például a helyi fürdőkben, múzeumokban stb., így a jegyeladások alapján megkülönböztethetők az egyes keresleti szegmensek (de egy egyszerủ lakcímkártya is igazolhatja a kedvezményes belépésre való jogosultságot).

3 Üdülőingatlanként az építészeti hatóságilag, lakásstatisztikailag ekként értelmezhető épületek értendők. A valóságban állandó (egész éves) lakhatásra alkalmas ingatlanokat üdülőként is hasznosíthatnak (tehát kizárólag rekreációs, szabadidős célból, átmenetileg veszik igénybe), de a fordítottja is előfordul, üdülőként nyilvántartott épületek állandóan lakottak. Ezt a jelenséget statisztikailag rendkívül nehéz megragadni.

\section{Köszönetnyilvánítás}

A tanulmányban közreadott eredmények feltárását egyrészt az OTKA K 100953 „Magyarország láthatatlan turizmusa", másrészt az MTA Posztdoktori Kutató Program (témavezető: Karácsonyi Dávid) támogatta. E helyen szeretnénk köszönetet mondani a Lechner Nonprofit Kft.-nek, amely rendelkezésünkre bocsátotta az Országos Területfejlesztési és Területrendezési Információs Rendszer (TeIR) adatállományát, és közreműködött az eredmények értelmezésében.

\section{Irodalom}

Asero, V. (2009): Tourism development and the "hidden' phenomenon. The Annals of "Dunarea de Jos" University of Galati Fascicle I - Economics and Applied Informatics, 1., 29-32. 
Aubert A., Papp J. (2015): Kisújbánya - az újraértelmezett „üdülőfalu”. In: Keczeli L., Kovács I., Nezdei Cs. (szerk.): Geográfus körút 60: Mohos Mária. Virágmandula Kft., Pécs, 11-26.

Baade, R., Dye, R. (1990): The impact of stadiums and professional sports on metropolitan area development. Growth and Change, 2., 1-14. http://doi.org/c47637

Bánhidi M. (2016): Rekreológia. Magyar Sporttudományi Társaság, Budapest

Beluszky P. (1999a): Magyarország településföldrajza. Általános rész. Dialóg Campus Kiadó, Budapest, Pécs

Beluszky P. (1999b): A budapesti agglomeráció kialakulása. In: Barta Gy., Beluszky P. (szerk.): Társadalmi-gazdasági átalakulás a budapesti agglomerációban I. Regionális Kutatási Alapítvány, Budapest, 27-68.

Beluszky P., Kovács Z. (1998): Város a térben: városszerkezet, városrészek, agglomeráció. In: Beluszky P., Kovács Z. (szerk.): Budapest kézikönyve 1. kötet: A fơváros általános leírása. CEBA Kiadó, Budapest, 99-123.

Csordás L. (1993): Szabadidő-lakások az Alföldön. Tér és Társadalom, 3-4., 75-103.

Csordás L. (2010): A magánüdülők építése és állománya Magyarországon. In: Mezei I., Hardi T., Koós B., Barabas D., Gallay M., Kandráčová, V. (szerk.): Földrajzi szemelvények határok nélkül: Napjaink magyar és szlovák természet-, társadalom- és gazdaságföldrajzi írásaiból. MTA Regionális Kutatások Központja, Pécs, 111-115.

Dahms, F., McComb, J. (1999): 'Counterurbanization', interaction and functional change in a rural amenity area - a Canadian example. Journal of Rural Studies, 2., 129-146. http://doi.org/czxdj4

De Cantis, S., Parroco, A., Ferrante, M., Vaccina, F. (2015): Unobserved tourism. Annals of Tourism Research, January, 1-18. http://doi.org/f62r27

Dövényi Z., Kovács Z. (1999): A szuburbanizáció térbeni-társadalmi jellemzői Budapest környékén. Földrajzi Értesíto", 1-2., 33-57.

Evert, M. (2008): Summing small cities does not make a large city: polycentric urban regions and the provision of cultural, leisure and sports amenities. Urban Studies, 11., 2323-2342.

Frisnyák S. (1990): Általános gazdaságföldrajz. Tankönyvkiadó, Budapest

Hall, M., Müller, D. (eds.) (2004): Tourism, mobility and second homes between elite landscape and common ground. Channel View Publications, Clevedon

Horváth B. (2006): A közlekedési kapcsolatok fejlődése Budapesten és agglomerációjában a fóváros egyesitésétól napjainkig. PhD értekezés. Pécsi Tudományegyetem, Pécs

Hwang, Y., Gretzel, U., Fesenmaier, D. (2006): Multicity trip patterns: tourists to the United States. Annals of Tourism Research, 4., 1057-1078. http://doi.org/b2tjmh

Jászberényi M., Pálfalvi J. (szerk.) (2009): Nemzetközi közlekedés és turizmus. Aula Kiadó, Budapest

Kádár, B., Gede, M. (2013): Where do tourists go? Visualizing and analysing the spatial distribution of geotagged photography. Cartographica: The International Journal for Geographic Information and Geovisualization, 2., 78-88. http://doi.org/b96r

Kiss, R. (2014): The geographical position, system and modelling of golf tourism. Hungarian Geographical Bulletin, 2., 201-220. http://doi.org/b96t

KSH (2001): Tájékoztatási adatbázis. KSH, Budapest

KSH (2014): Magyarország településhálózata 1. Agglomerációk, településegyüttesek. KSH, Budapest

KSH (2016): Jelentés a turizmus és a vendéglátás teljesitményéról, 2016. KSH, Budapest http://www.ksh.hu/docs/hun/xftp/idoszaki/jeltur/jeltur15.pdf (Letöltés: 2017. július 31.)

Liu, M., Li, K., Tang, Q., Wang, L., Li, Y. (2015): To withstand loneliness in the process of urbanisation: research on the construction and planning of metropolitan suburban rural tourism scenic areas. Agricultural Science \& Techonolgy, 3., 615-621.

Lo, I., McKercher, B., Lo, A., Cheung, C., Law, R. (2011): Tourism and online photography. Tourism Management, 4., 725-731. http://doi.org/d59r6g

Michalkó G., Rátz T. (2013): Rejtett dimenziók a Kárpát-medence turizmusában. In: Frisnyák S., Gál A. (szerk.): Kárpát-medence: természet, társadalom, gazdaság. Bocskai István Gimnázium, Nyíregyházi Főiskola, Szerencs, Nyíregyháza, 463-476.

Michalkó G., Kádár B., Gede M., Balizs D., Kondor A., Ilyés N. (2016): A budapesti agglomeráció szatellitturizmusának környezeti hatásai. In: Sikos T. T., Tiner T. (szerk.): Tájak, régiók, települések térben és idóben: tanulmánykötet Beluszky Pál 80. születésnapjára. Dialóg Campus Kiadó, Budapest, 241-257. 
Mills, B., Rosentraub, M. (2013): Hosting mega-events: a guide to the evaluation of development effects in integrated metropolitan regions. Tourism Management, 2., 238-246. http://doi.org/b96v

Nucciarelli, A., Gastaldi, M. (2009): Collaboration in the airport business through the development of an IT platform. International Journal of Production Economics, 2., 562-573. http://doi.org/dv48wc

Ostertag, J., Wöber, K. (2010): European city tourism statistics. In: Mazanec, J., Wöber, K. (eds.): Analysing international city tourism. Springer, Wien, 25-41. http://doi.org/cb2b28

Pintilii, R., Merciu, F., Peptenatu, D., Cercleux, A., Drăghici, C. (2011): Sports and leisure time tourism - a way of revitalising emergent spaces from the metropolitan area of Bucharest. Analele Universităţii din Oradea - Seria Geografie, 2., 323-332.

Rátz, T., Kundi, V., Michalkó, G. (2015): The hidden dimensions of cultural consumption within the framework of tourism mobility. In: Sonnenburg, S., Wee, D. (eds.): Touring consumption. Springer, Wiesbaden, 285-302. http://doi.org/b96w

Rátz, T., Puczkó, L. (2002): The impacts of tourism: an introduction. Häme Polytechnic, Hämeenlinna

Sava, C., Caraivan, L. (2012): The durable development of cultural tourism in Timisoara and its surrounding area: capitalizing on the existing assets and resources. Review of Applied SocioEconomic Research, 2., 217-224.

Selby, M. (2004): Understanding urban tourism. Image, culture and experience. I. B. Tauris, London

Spirou, C. (2011): Urban tourism and urban change. Cities in a global economy. Routledge, Oxon

Stan, M., Țenea, D., Vintilă, D. (2014): Developing strategy for sustainable tourism. Case study: Constanta Metropolitan Area. Urbanism. Arhitectură Construcţiii, 3., 5-16.

Straumann, R., Çöltekin, A., Andrienko, G. (2014): Towards (re)constructing narratives from georeferenced photographs through visual analytics. The Cartographic Journal, 2., 152-165. http://doi.org/f56rzs

Teller, C., Elms, J. (2012): Urban place marketing and retail agglomeration customers. Journal of Marketing Management, 5-6., 546-567. http://doi.org/b25k3m

Timothy, D. (2004): Shopping tourism, retailing and leisure. Channel View Publications, Bristol

Tiner T. (2015): A térség közlekedési infrastruktúrájának kiépülése és fejlődése. In: Sikos T T. (szerk.): A budapesti agglomeráció nyugati kapuja: Budaörs, Törökbálint, Biatorbágy. Szent István Egyetemi Kiadó, Budapest, 143-156. http://doi.org/b96x

Torreggiani, D., Dall'Ara, E., Tassinari, P. (2012): The urban nature of agriculture: bidirectional trends between city and countryside. Cities, 6., 412-416. http://doi.org/fzgb8j

Tömöri, M. (2012): Retail without borders: the example of Debrecen (Hungary) and Oradea (Romania). Central European Regional Policy and Human Geography, 1., 53-62.

Tuohino, A., Dávid, L. (2012): Global problems, local solutions: the case of lake tourism development. Tourism Today: The Journal of the College of Tourism and Hotel Management, Autumn., 134-150.

UNESCO (2016): UNESCO World Heritage List. http://whc.unesco.org/en/list (Letöltés: 2016. október 25.)

Vepsäläinen, M., Pitkänen, K. (2010): Second home countryside. Representations of the rural in Finnish popular discourses. Journal of Rural Studies, 2., 194-204. http://doi.org/fq7pfg

Wood, S., Guerry, A., Silver, J., Lacayo, M. (2013): Using social media to quantify nature-based tourism and recreation. Scientific Report, 2976., 1-7. http://doi.org/pbc

Yang, Y. (2012): Agglomeration density and tourism development in China: an empirical research based on dynamic panel data model. Tourism Management, 6., 1347-1359. http://doi.org/fx5szh

Zeng, D., Zhu, X. (2011): Tourism and industrial agglomeration. The Japanese Economic Review, 4., 537-561. http://doi.org/dqxmzq

Zuelow, E. (2016): A history of modern tourism. Palgrave, London http://www.nepszamlalas2001.hu/hun/kotetek/15/15_osszef.pdf (Letöltés: 2016. november 19.) 